\title{
Development of Fermented Beverage Using RSM and Nutrients Evaluation - I. Fermented Ashgourd Beverage
}

\author{
C. S. Devaki ${ }^{1} \&$ K. S. Premavalli ${ }^{1}$ \\ ${ }^{1}$ Food Preservation Discipline, Defence Food Research Laboratory, Mysore, India \\ Correspondence: K. S. Premavalli, Food Preservation Discipline, Defence Food Research Laboratory, \\ Siddarthanagar, Mysore 570011, Karnataka, India. Tel: 91-821-247-3828. E-mail: dfrlmysore@sancharnet.in
}

Received: January 6, 2012 Accepted: January 19, 2012 Online Published: July 2, 2012

doi:10.5539/jfr.v1n3p138 URL: http://dx.doi.org/10.5539/jfr.v1n3p138

\begin{abstract}
Ash gourd (Benincasa hispida) is valued for its nutritive and medicinal properties and further value addition is being attempted by fermentation process. In the present study, the optimization of the fermentation process with reference to yeast concentration and the period has been attempted by using RSM. The statistical design gave 13 formulations, where yeast concentration was from 1 to $5.8 \%$ and the fermentation process period varied from 0.5 to 17.5 days. The product varied formulations had total phenols ranged from 24.8 to $43.6 \mathrm{mg} \%$, antioxidant 12.3 to $27 \%$, acidity 0.067 to $0.6 \%$, total volatiles 0.0025 to $0.078 \%$, alcohol $4.6-12.4 \%$, overall acceptability 6.9 to 8.4 , thiamine 115.7 to $367 \mu \mathrm{g} \%$, riboflavin 32.4 to $159 \mu \mathrm{g} \%$, niacin 6.7 to $139.4 \mu \mathrm{g} \%$, pyridoxine 71.68 to $174.1 \mu \mathrm{g} \%$ and vitamin $\mathrm{C}$ from 0.02 to $0.21 \mathrm{mg} \%$. Yeast concentration of $3 \%$ and fermentation time for 3 days was the optimized process conditions achieved with the best fit of desirability 0.92 .
\end{abstract}

Keywords: ashgourd, dry yeast, fermentation, rSM, vitamins

\section{Introduction}

Ash gourd (Benincasa hispida), a member of the family Cucurbitaceae is one of the familiar crops that are grown primarily for its use as a vegetable and usually recognized for its nutritional and medicinal properties especially in Asian countries. As a rich source of functionally important bioactives and therapeutics such as triterpenes, phenolics, sterols, glycosides and soluble dietary fiber the vegetable has been widely used for therapeutic treatments. (Gupta \& Premavalli, 2010; Sivarajan \& Balachandran, 1994; Aslokar et al., 1992)

Ashgourd is widely cultivated throughout the world and stored in the whole form that it is available all the year round. In India, ashgourd is used in curries or is coated with sugar or syrup and eaten as a sweet and recently Majumdar et al. $(2009 ; 2010)$ have reported on the stabilization of ashgourd juice and ashgourd blended juice. However the fermentation process improves the quality in terms of nutrients and flavour. Therefore, an attempt has been made to develop fermented ashgourd beverage by optimization of the process with commercially available dry yeast and the study is oriented towards the analysis of nutritional profile of the product.

Fermented foods provide several health benefits. Though vegetables are often used for fermentation in other countries (Yoon et al., 2006; Filomena et al., 2008) it is less commonly used in India. Vegetables being good source of vitamins and minerals, further availability can be improved by fermentation process (Campbell, 1994; Marica et al., 2007). Fermentation process is known for improving digestibility and flavour. As well Yoon, et al. (2006) showed that Fermented cabbage juice serve as a healthy beverage for vegetarians and lactose - allergic consumers. Beetroot and carrot juices were fermented with the use of brewer's yeast autolysate by Marica et al. (2007); while 3-5\% yeast with 10-12days was followed by Joshi and Attri (2005) for fermentation of apple, plum and pear juices.

However, the studies on nutrient profile has not received much attention thus the fermentation conditions followed for vegetable juices and the changes in their nutrients still needs a radical approach to achieve the best quality product. Therefore in the present study, the strengthful raw material ashgourd, statistical design using RSM, an effective tool for optimization have been used with an attempt to bring out the nutritional strength of the fermentation process. 


\section{Materials and Methods}

\subsection{Materials}

Good quality raw materials i.e. ash gourd (Benincasa hispida), dry yeast and sugar were procured from local market. All the chemical and reagents used for the analysis were AR grade. For HPLC analyses HPLC grade solvents and standards were procured from M/s SK Chemicals, Burdick and Jackson, HPLC certified solvents and M/s Sigma Aldrich, St. Louis, USA.

\subsection{Raw Material Processing}

Ash gourd was de-skinned, removed the rind portion, and cut into pieces, blanched at $90^{\circ} \mathrm{C}$ for 3 mins and extracted the juice using a juice extractor (RayLons Metal Works, Bombay, India). The extracted juice was processed further using sugar syrup. Yeast was added (1- 5.8\%) and fermented at room temperature for 0.5 to 17.5 days period.

\subsection{Experimental Design}

The percentage of yeast and time of fermentation was as per the runs obtained by design expert statistical software. A Central Composite Rotatable Design was used without blocking. The number of design points was obtained on basis of the number of independent variables decided. The statistical software package design expert 8.0.2, Stat - Ease Inc., Minneapolis, MN, was used to construct the experimental design as well as analyze the data. The parameters that influence the product quality, acceptability and functionality were taken as responses. Variables Dry Yeast concentration and fermentation period were selected as independent variables and total phenols (mg\%), antioxidants (\%), Water soluble vitamins $(\mu \mathrm{g} \%)-\mathrm{B}_{1}, \mathrm{~B}_{2}, \mathrm{~B}_{3}, \mathrm{~B}_{6}$, vitamin- $\mathrm{C}(\mathrm{mg} \%)$, acidity $(\%)$,total volatiles (\%), alcohol (\%) and Organoleptic evaluation (score) were selected as the responses. The factorial design considered 4 factorial points, 4 axial points and 5 central points leading to 13 sets of experiments (Wadikar et al., 2010). Optimized ranges of the variables are shown in Table 1. Each independent variable investigated in this experiment had five levels which were $-1.4142,-1,0,+1$ and +1.4142 . A total of 13 level combinations (design points) were generated for the two independent variables and the alpha values in the design outside the ranges were selected for rotatability of the design. The center point (the level combination in which the value of each coded variable was 0 ) was repeated five times for the two-variable design and was selected keeping the ingredients at levels expected to yield, at least, satisfactory experimental results.

Table 1. Process variables their levels and experimental design

\begin{tabular}{llllll}
\hline Process variables & -1.414 & -1 & 0 & +1 & +1.414 \\
& $\begin{array}{l}\text { (augmented } \\
\text { form) }\end{array}$ & $\begin{array}{l}\text { (factorial } \\
\text { point) }\end{array}$ & $\begin{array}{l}\text { (centre } \\
\text { point) }\end{array}$ & $\begin{array}{l}\text { (factorial } \\
\text { point) }\end{array}$ & $\begin{array}{l}\text { (augmented } \\
\text { form) }\end{array}$ \\
\hline Dry yeast (\%) & 0.17 & 1 & 3 & 5 & 5.83 \\
Fermentation (Days) & 0.51 & 3 & 9 & 15 & 17.49 \\
\hline
\end{tabular}

\begin{tabular}{lll}
\hline $\mathrm{X}_{1}$ & $\mathrm{X}_{2}$ & Runs \\
\hline \pm 1 & \pm 1 & 4 \\
$\pm \quad 1.414$ & 0 & 2 \\
0 & \pm 1.414 & 2 \\
0 & 0 & 5 \\
\hline
\end{tabular}

The regression analysis of the responses was conducted by fitting to the suitable model represented by the following equation

$$
Y=\beta_{0}+\sum_{i=1}^{n} \beta_{i} X_{i}+\sum_{i=1}^{n} \beta_{i i} X_{i}^{2}+\sum_{i \neq j=1}^{n} \beta_{i i} X_{i} X_{i j}
$$

Where, $\beta_{\mathrm{o}}$ was the value of the fitted response at the center point of the design, while $\beta_{\mathrm{i}}, \beta_{\mathrm{ii}}$, and $\beta_{\mathrm{ij}}$ were the linear, quadratic and interactive-effect regression terms, respectively, and $n$ denoted the number of independent variables i.e. in this case $n$ is 2 , and $\mathrm{x}_{\mathrm{i}}, \mathrm{x}_{\mathrm{ij}}$ are independent variables in coded values represented by $\mathrm{X}_{1}$ and $\mathrm{X}_{2}$ in 
Table 2.

Table 2. Actual experimental combinations and response values

\begin{tabular}{|c|c|c|c|c|c|c|c|c|c|c|c|c|c|}
\hline $\begin{array}{l}\text { Exp. } \\
\text { No }\end{array}$ & $\mathrm{X}_{1}$ & $\mathrm{X}_{2}$ & $\begin{array}{l}\text { Total } \\
\text { Pheno } \\
\text { ls }\end{array}$ & $\begin{array}{l}\text { Antioxi } \\
\text { dants }\end{array}$ & Acidity & $\begin{array}{l}\text { Total } \\
\text { Volatile } \\
\mathrm{s}\end{array}$ & $\begin{array}{l}\text { Alcoh } \\
\text { ol }\end{array}$ & $\mathrm{OAA}^{*}$ & $\begin{array}{l}\text { Thiami } \\
\text { ne }\end{array}$ & $\begin{array}{l}\text { Riboflav } \\
\text { in }\end{array}$ & $\begin{array}{l}\text { Niaci } \\
n\end{array}$ & $\begin{array}{l}\text { Pyridoxi } \\
\text { ne }\end{array}$ & $\begin{array}{l}\text { Vitamin- } \\
\mathrm{C}\end{array}$ \\
\hline & & & $\mathrm{mg} \%$ & $\%$ & $\%$ & $\%$ & $\%$ & Score & $\mu \mathrm{g} \%$ & $\mu \mathrm{g} \%$ & $\mu \mathrm{g} \%$ & $\mu \mathrm{g} \%$ & $\mathrm{mg} \%$ \\
\hline & & & $\mathrm{Y}_{1}$ & $\mathrm{Y}_{2}$ & $\mathrm{Y}_{3}$ & $\mathrm{Y}_{4}$ & $\mathrm{Y}_{5}$ & $\mathrm{Y}_{6}$ & $\mathrm{Y}_{7}$ & $\mathrm{Y}_{8}$ & $\mathrm{Y}_{9}$ & $\mathrm{Y}_{10}$ & $\mathrm{Y}_{11}$ \\
\hline & 1 & 3 & 24.8 & 14.7 & 0.14 & 0.0089 & 8.2 & $\begin{array}{l}7.98 \pm 0 . \\
07\end{array}$ & 36.7 & 153.7 & 6.70 & 95.50 & 0.02 \\
\hline & 5 & 3 & 37.2 & 15.3 & 0.28 & 0.0029 & 4.6 & $\begin{array}{l}7.73 \pm 0 . \\
01\end{array}$ & 115.7 & 46.50 & 66.8 & 166.0 & 0.16 \\
\hline & 1 & 15 & 30.1 & 24.8 & 0.37 & 0.0420 & 5.7 & $\begin{array}{l}6.91 \pm 0 . \\
54\end{array}$ & 142.0 & 32.40 & 29.4 & 149.4 & 0.04 \\
\hline & 5 & 15 & 43.6 & 27.46 & 0.61 & 0.0420 & 12.4 & $\begin{array}{l}7.19 \pm 0 . \\
21\end{array}$ & 223.0 & 140.2 & $\begin{array}{l}132 . \\
1\end{array}$ & 129.8 & 0.19 \\
\hline & $\begin{array}{l}0.1 \\
7\end{array}$ & 9 & 24.8 & 20.3 & 0.31 & 0.0045 & 7.6 & $\begin{array}{l}7.02 \pm 0 . \\
11\end{array}$ & 281.4 & 130.4 & 15.1 & 150.1 & 0.04 \\
\hline & $\begin{array}{l}5.8 \\
3\end{array}$ & 9 & 43.3 & 22.1 & 0.57 & 0.0039 & 9.8 & $\begin{array}{l}7.07 \pm 0 . \\
09\end{array}$ & 150.1 & 107.6 & $\begin{array}{l}139 . \\
4\end{array}$ & 174.1 & 0.18 \\
\hline & 3 & $\begin{array}{l}0.5 \\
1\end{array}$ & 29.89 & 12.3 & 0.07 & 0.0025 & 4.9 & $\begin{array}{l}8.38 \pm 0 . \\
56\end{array}$ & 251.5 & 96.40 & 16.5 & 87.00 & 0.06 \\
\hline & 3 & $\begin{array}{l}17 . \\
49\end{array}$ & 37.8 & 27.61 & 0.46 & 0.0780 & 8.6 & $\begin{array}{l}7.27 \pm 0 . \\
21\end{array}$ & 166.1 & 66.70 & 64.0 & 76.60 & 0.10 \\
\hline & 3 & 9 & 32.7 & 18.0 & 0.48 & 0.0190 & 4.9 & $\begin{array}{l}7.1 \pm 0.2 \\
2\end{array}$ & 216.5 & 113.7 & 19.7 & 129.5 & 0.21 \\
\hline & 3 & 9 & 31.5 & 18.0 & 0.48 & 0.0051 & 5.0 & $\begin{array}{l}7.1 \pm 0.2 \\
2\end{array}$ & 212.7 & 133.6 & 35.2 & 71.70 & 0.19 \\
\hline & 3 & 9 & 32.1 & 17.8 & 0.47 & 0.0056 & 4.9 & $\begin{array}{l}7.2 \pm 0.2 \\
9\end{array}$ & 210.1 & 114.7 & 20.5 & 132.5 & 0.18 \\
\hline & 3 & 9 & 32.0 & 17.2 & 0.47 & 0.0053 & 4.9 & $\begin{array}{l}7.1 \pm 0.3 \\
6\end{array}$ & 222.0 & 137.7 & 24.4 & 79.40 & 0.17 \\
\hline & 3 & 9 & 31.5 & 17.6 & 0.47 & 0.0059 & 4.9 & $\begin{array}{l}7.2 \pm 0.4 \\
0\end{array}$ & 218.9 & 159.0 & 14.2 & 92.60 & 0.20 \\
\hline
\end{tabular}

Note: * Over All Acceptability (OAA) scored on nine point Hedonic scale.

After fermentation for varied periods the respective samples were filtered in muslin cloth immediately and centrifuged to get a clear juice. Then the bottles were sealed and pasteurized for $15 \mathrm{mins}$ at $90^{\circ} \mathrm{C}$. The samples were analysed immediately after the completion of the fermentation process.

\subsection{Analytical Evaluation}

The fermented ashgourd juice was analysed for total phenols and free radical scavenging capacity (DPPH activity) (Sandra et al., 2009), acidity (Ranganna, 1986), total volatiles (AOAC, 1970) and alcohol by HPLC on reverse phase $C_{18}$ column with isocratic elution of solvent orthophosphoric acid and water at $0.8 \mathrm{ml} / \mathrm{min}$, with UV detector $(215 \mathrm{~nm})$. Water Soluble Vitamins i.e., thiamine, riboflavin, niacin, pyridoxine and vitamin $\mathrm{C}$ analyses were performed using HPLC on reverse phase $\mathrm{C}_{18}$ analytical column (Knauer, 2010).

The analysis for all the parameters was carried out in duplicate and the average value has been reported. 


\subsection{Organoleptic Evaluation}

A Semi trained panel evaluated the samples for color, aroma, taste, consistency and overall acceptability using a nine-point hedonic scale (Majumdar et al., 2010). Samples were randomly drawn for each experimental block, coded and served to the panelists.

\section{Results and Discussions}

The experimental central composite rotatable design with independent variables and responses is given in Table 2 . Since overall acceptability is an important criterion for the product acceptance, it has been taken as one of the responses. Over the 13 combinations total phenols ranged from 24.8 to $43.6 \mathrm{mg} \%$, antioxidant 12.3 to $27 \%$, acidity 0.067 to $0.6 \%$, total volatiles 0.0025 to $0.078 \%$, alcohol $4.6-12.4 \%$, Overall acceptability 6.9 to 8.4 , thiamine 115.7 to $367 \mu \mathrm{g} \%$, riboflavin 32.4 to $159 \mu \mathrm{g} \%$, niacin 6.7 to $139.4 \mu \mathrm{g} \%$, pyridoxine 71.68 to $174.1 \mu \mathrm{g} \%$ and vitamin $\mathrm{C}$ from 0.02 to $0.21 \mathrm{mg} \%$.

The effects of the independent variables yeast and fermentation time on the response at linear, quadratic and interactive levels are presented in Table 3. The sign and magnitude of the coefficients indicate the effect of the variable on the responses. Negative sign of a coefficient at linear level indicates decrease in response with an increase in level of the variable where as at interactive level; level of one variable could be increased while that of the other decreased to obtain the same response.

Table 3. Coefficient of second order polynomial regression models

\begin{tabular}{|c|c|c|c|c|c|c|c|c|c|c|c|}
\hline Coefficient & $\begin{array}{l}\text { Total } \\
\text { Phenols }\end{array}$ & Antioxidants & Acidity & $\begin{array}{l}\text { Total } \\
\text { Volatiles }\end{array}$ & Alcohol & OAA* & Thiamine & Riboflavin & Niacin & Pyridoxine & Vitamin-C \\
\hline & $\mathrm{mg} \%$ & $\%$ & $\%$ & $\%$ & $\%$ & Score & $\mu \mathrm{g} \%$ & $\mu \mathrm{g} \%$ & $\mu \mathrm{g} \%$ & $\mu \mathrm{g} \%$ & $\mathrm{mg} \%$ \\
\hline & $\mathrm{Y}_{1}$ & $\mathrm{Y}_{2}$ & $\mathrm{Y}_{3}$ & $\mathrm{Y}_{4}$ & $\mathrm{Y}_{5}$ & $\mathrm{Y}_{6}$ & $\mathrm{Y}_{7}$ & $\mathrm{Y}_{8}$ & $\mathrm{Y}_{9}$ & $\mathrm{Y}_{10}$ & $\mathrm{Y}_{11}$ \\
\hline$\beta_{0}$ & 31.95 & 17.7 & 0.47 & 0.008 & 4.92 & 7.14 & 216.02 & 131.7 & 22.8 & 101.1 & 0.18 \\
\hline$\beta_{1}$ & $6.50 * * * *$ & $0.72 * * *$ & $0.09 * * * *$ & -0.0008 & $0.79 * * * *$ & 0.012 & $-44.48 * * * *$ & -3.95 & $42.3 * * * *$ & 10.6 & $0.069 * * *$ \\
\hline$\beta_{2}$ & $2.85 * * * *$ & $5.49 * * * *$ & $0.139^{* * * *}$ & $0.022 * * * *$ & $1.31 * * * *$ & $-0.39 * * * *$ & $-29.8 * * * *$ & -8.69 & $19.39 * * * *$ & 0.38 & 0.013 \\
\hline$\beta_{11}$ & $1.03 * * *$ & $1.7 * * * *$ & $-0.017 * * * *$ & -0.0015 & $1.87 * * * *$ & $-0.042 *$ & -0.22 & -8.13 & $27.2 * * * *$ & $33.7 * *$ & $-0.033^{* *}$ \\
\hline$\beta_{22}$ & $0.936^{* * *}$ & $1.1 * * * *$ & $-0.105^{* * * *}$ & $0.016^{* * *}$ & $0.9^{* * * *}$ & $0.34 * * * *$ & -3.69 & $-26.8^{* *}$ & $8.7^{*}$ & -6.34 & $-0.048^{* *}$ \\
\hline$\beta_{12}$ & 0.275 & $0.515^{* *}$ & $0.025^{* * * * *}$ & 0.0015 & $2.58 * * * *$ & $0.1325^{* * *}$ & $83.07 * * * *$ & $53.7 * * *$ & $10.7^{*}$ & -22.53 & 0.0025 \\
\hline $\mathrm{R}^{2} \%$ & 99.75 & 99.76 & 99.95 & 95.16 & 99.99 & 99.41 & 99.75 & 91.32 & 98.63 & 75.84 & 92.62 \\
\hline $\mathrm{p} \%$ & $<0.0001$ & $<0.0001$ & $<0.0001$ & $<0.001$ & $<0.0001$ & $<0.0001$ & $<0.0001$ & $<0.01$ & $<0.0001$ & $<0.05$ & $<0.001$ \\
\hline Mean & 33.18 & 19.47 & 0.40 & 0.02 & 6.63 & 7.33 & 213.61 & 110.20 & 44.93 & 118.01 & 0.13 \\
\hline SD & 0.384 & 0.283 & 0.0046 & 0.0066 & 0.034 & 0.043 & 4.188 & 15.392 & 6.766 & 23.054 & 0.024 \\
\hline F-value & 563.95 & 681.67 & 2868.48 & 27.54 & 12767.9 & 238.89 & 577.45 & 14.73 & 101.11 & 4.39 & 17.57 \\
\hline
\end{tabular}

Note 1: Significance: ${ }^{* * * *} \mathrm{p}>0.0001,{ }^{* * *} \mathrm{p}<0.001,{ }^{* *} \mathrm{p}<0.01,{ }^{*} \mathrm{p}<0.05$.

Note 2: * Over All Acceptability (OAA) scored on nine point Hedonic scale.

All main, linear, quadratic and interactive effects were calculated for each model. Quadratic response surface models were selected for all the responses. The adequacy was calculated by F-ratio, mean, standard deviation, coefficient correlation and lack of fit test. $\mathrm{R}^{2}$ value was more than $90 \%$ and lack of fit was highly non-significant. The regression coefficient, correlation coefficient for the responses were 0.99 for total phenols, antioxidants, acidity, alcohol, overall acceptability, $\mathrm{B}_{1}, \mathrm{~B}_{3}$ and 0.95 for total volatiles, 0.93 for vitamin $\mathrm{C}, 0.91$ for $\mathrm{B}_{2}$ respectively indicating that all the values were more than $90 \%$. The $\mathrm{R}^{2}$ value for $\mathrm{B}_{6}$ was 0.76 , but because of the subjective nature of the response the model is considered significant. 


\subsection{Effect of Variables on Functional Parameters}

Total phenols and antioxidants were considered as functional parameters for the independent variables. Abbas (2006) reported that yeasts can also synthesize a number of bioactive compounds which can serve as antioxidants. Several Candida and Saccharomyces species produce compounds such as caroteniods, citric acid, glutathione and tocopherols with interesting antioxidant properties while Cruz et al. (1999) reported that the formation of these substances can be induced in yeasts grown under stressing conditions or in response to fermentation medium ingredients such us phenolics or additives that are known to be toxic to cells grown aerobically. Table 3 reveals that at linear level, yeast and fermentation time had a significant $(\mathrm{p}<0.001)$ positive effect on total phenols and antioxidants. At quadratic level both yeast and fermentation time a positive highly significant level at $\mathrm{p}<0.0001$ for antioxidants and $\mathrm{p}<0.001$ on total phenols. Yeast and fermentation time has positive significant effect $(\mathrm{p}<0.01)$ on antioxidant level at interactive level. The multiple coded equations in terms of coded factors generated for their responses are shown below:

$$
\begin{array}{ll}
\text { Total Phenols }=31.96+6.506 \mathrm{X}_{1}+2.859 \mathrm{X}_{2}+1.038 \mathrm{X}_{1}^{2}+0.936 \mathrm{X}_{2}^{2}+0.275 \mathrm{X}_{1} \mathrm{X}_{2} & \mathrm{R}^{2}=0.99 \\
\text { Antioxidants }=17.719+0.725 \mathrm{X}_{1}+5.487 \mathrm{X}_{2}+1.735 \mathrm{X}_{1}^{2}+1.113 \mathrm{X}_{2}^{2}+0.515 \mathrm{X}_{1} \mathrm{X}_{2} & \mathrm{R}^{2}=0.99
\end{array}
$$

The response surface for total phenols and antioxidants in relation to yeast and fermentation time is shown in Figures $1 \mathrm{a}$ and $1 \mathrm{~b}$ respectively. As yeast concentration increased total phenols increased and as fermentation increased there was increase in antioxidant level of beverage.
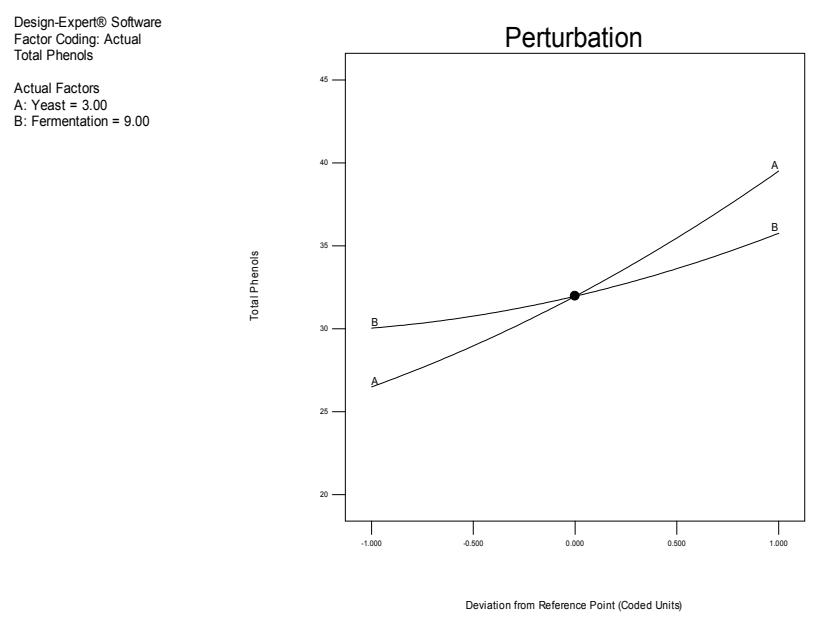

1a. Total Phenols
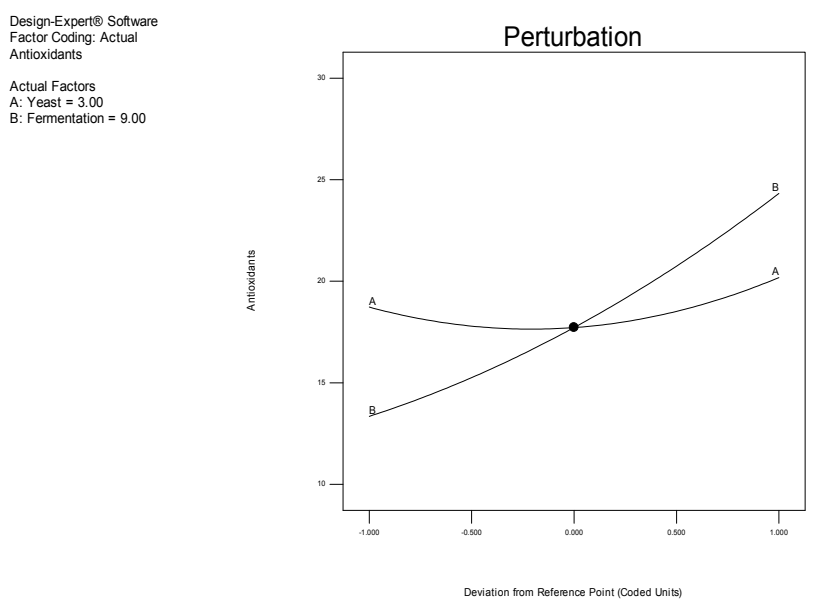

1b. Antioxidant

Figure 1. Perturbation graphs depicting effect of independent variables on total phenols and antioxidant levels of the fermented beverage 


\subsection{Effect of Variables on Quality parameters}

Acidity, overall acceptability, alcohol and total volatiles were selected as quality parameters. At linear level yeast and fermentation time had a significant $(\mathrm{p}<0.0001)$ positive effect on acidity and alcohol, fermentation time had a significant $(p<0.0001)$ positive effect on total volatiles and overall acceptability was negatively affected $(p<0.0001)$, while yeast had negative effect on total volatiles. However, no significant effect of yeast had seen on total volatiles and overall acceptability. Effect of independent variable on sensory attributes such as flavour, taste, consistency and colour is given in Table 4 .

Table 4. Sensory score of optimized composition, $n=10$

\begin{tabular}{cccccc}
\hline Sl. No & Flavour & Taste & Consistency & Colour & OAA $^{*}$ \\
\hline 1 & 7.9 & 7.9 & 8 & 8.1 & 7.9 \\
2 & 7.9 & 7.8 & 8 & 8.1 & 7.8 \\
3 & 7.8 & 7.8 & 8 & 8 & 7.8 \\
4 & 7.5 & 7.6 & 8 & 8 & 7.6 \\
5 & 7.9 & 7.9 & 8 & 8.2 & 7.9 \\
6 & 7.9 & 7.6 & 8 & 8.1 & 7.8 \\
7 & 7.6 & 7.6 & 8 & 8 & 7.6 \\
8 & 7.9 & 7.8 & 8 & 8 & 7.8 \\
9 & 7.8 & 7.8 & 8 & 8.1 & 7.9 \\
10 & 7.9 & 7.9 & 8 & 7.9 & 7.9 \\
Mean & 7.81 & 7.77 & 8.00 & 8.05 & 7.80 \\
SD \pm & 0.14 & 0.13 & 0.00 & 0.08 & 0.12 \\
\hline
\end{tabular}

Note: * Overall acceptability.

At quadratic level yeast effect on acidity, alcohol were significant at $\mathrm{p}<0.0001$, on overall acceptability at $\mathrm{p}<0.05$. Yeast had positive effect on alcohol, while acidity and OAA had negative effect and total volatiles was not significant. Fermentation time affected acidity, alcohol and OAA at $\mathrm{p}<0.0001$ and on total volatiles at $\mathrm{p}<0.001$. Total volatiles, alcohol and OAA had positive effect while acidity had negative effect. Variables had significant $(\mathrm{p}<0.0001)$ positive effect on acidity, alcohol and $\mathrm{p}<0.001$ on OAA, while total volatiles was not significant. Lopez et al. (2008) also showed a positive effect of fermentation process by confirming that yeast are present throughout the fermentative process and it is generally accepted that they can produce compounds with important organoleptic attributes determining the quality and flavour of the final product.

The multiple coded equations in terms of coded factors generated for their responses are shown below:

$$
\begin{array}{ll}
\text { Acidity }=0.474+0.0934 \mathrm{X}_{1}+0.139 \mathrm{X}_{2}-0.0175 \mathrm{X}_{1}^{2}-0.1056 \mathrm{X}_{2}^{2}+0.025 \mathrm{X}_{1} \mathrm{X}_{2} & \mathrm{R}^{2}=0.99 \\
\text { Total Volatiles }=0.0082-0.0008 \mathrm{X}_{1}+0.0224 \mathrm{X}_{2}-0.0015 \mathrm{X}_{1}^{2}+0.0165 \mathrm{X}_{2}^{2}+0.0015 \mathrm{X}_{1} \mathrm{X}_{2} & \mathrm{R}^{2}=0.95 \\
\text { Alcohol }=4.9+0.793 \mathrm{X}_{1}+1.319 \mathrm{X}_{2}+1.878 \mathrm{X}_{1}^{2}+0.907 \mathrm{X}_{2}^{2}+2.58 \mathrm{X}_{1} \mathrm{X}_{2} & \mathrm{R}^{2}=0.99 \\
\text { Overall Acceptability }=7.14+0.012 \mathrm{X}_{1}-0.397 \mathrm{X}_{2}-0.0429 \mathrm{X}_{1}^{2}+0.3465 \mathrm{X}_{2}^{2}+0.1325 \mathrm{X}_{1} \mathrm{X}_{2} & \mathrm{R}^{2}=0.99
\end{array}
$$

Figures $2 \mathrm{a}$ to $2 \mathrm{~d}$ represents the change in quality parameters of fermented beverage with respect to dry yeast concentration and fermentation time. It is clear from table that fermentation time influenced all quality parameters. As fermentation time increased there was increase in alcohol and total volatiles where as OAA decreased. Querol and Fleet (2006) reported that in wines, among the 1,000 volatile compounds identified, more than 400 are produced by yeasts. Esters produced by yeasts can contribute to both aroma and flavour and several factors can contribute to aroma production by yeasts. Increase in yeast concentration increased acidity and alcohol. 


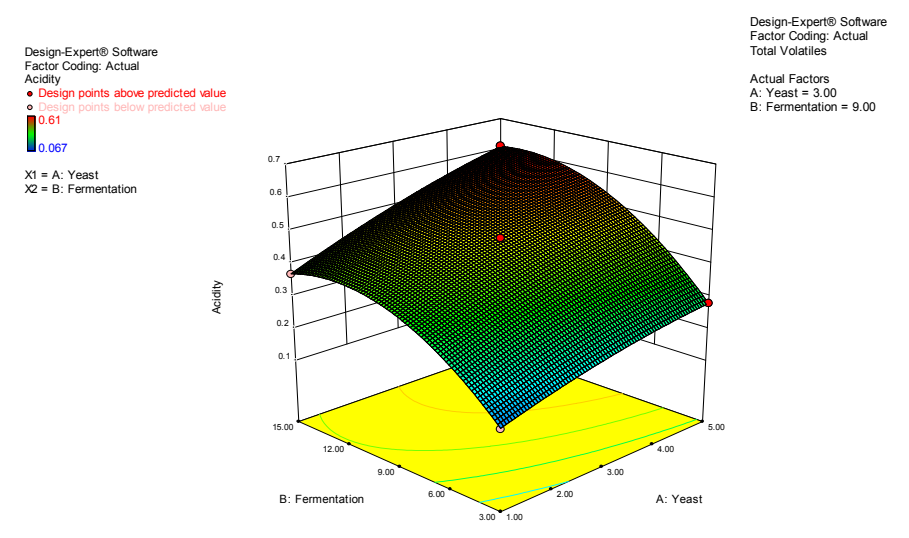

2a. Acidity

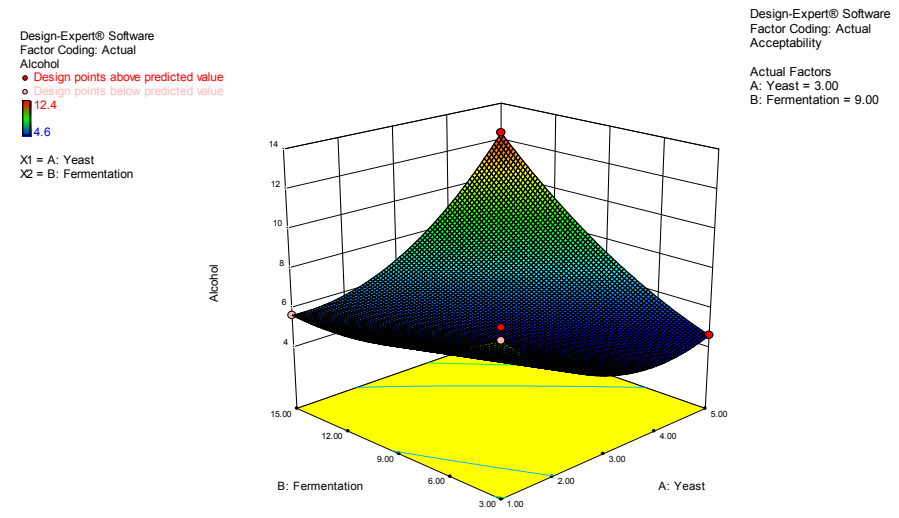

2c. Alcohol

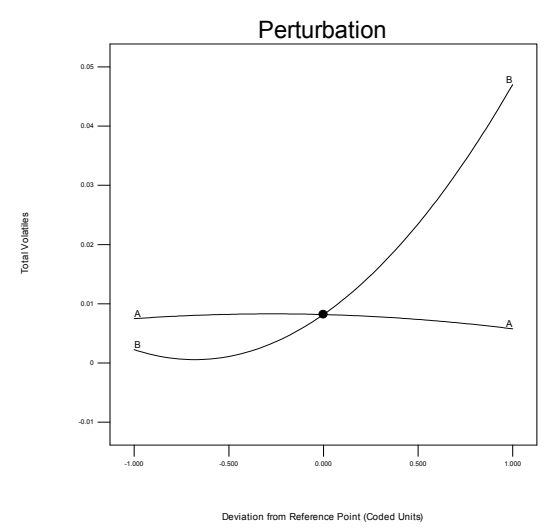

2b. Total Volatiles

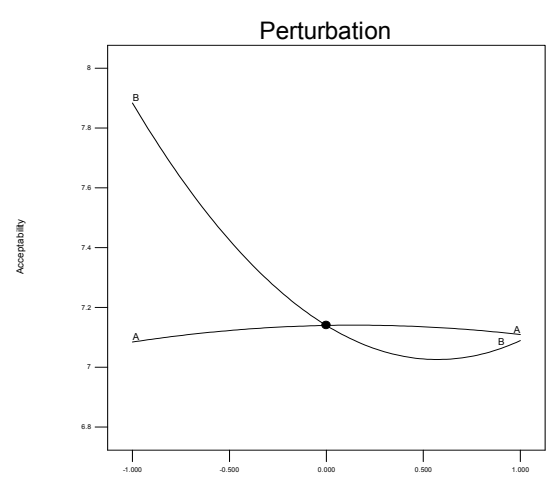

2d. Overall Acceptability

Figure 2. Perturbation graph and 3D plots depicting effect of independent variables on Quality Parameters of the fermented beverage

\subsection{Effect of variables on nutritional parameters}

Viljoen (2006) reported that yeasts appear to be active microorganisms synthesising substances such as vitamins, amino acids and purines, or breakdown complex carbohydrates which will have an impact on product. The model obtained from the regression can be written as follows for nutritional parameters.

$$
\begin{array}{ll}
\text { Thiamine }=216.03-44.4811 \mathrm{X}_{1}-29.8010 \mathrm{X}_{2}-0.2205 \mathrm{X}_{1}^{2}-3.6992 \mathrm{X}_{2}^{2}+83.075 \mathrm{X}_{1} \mathrm{X}_{2} & \mathrm{R}^{2}=0.99 \\
\text { Riboflavin }=131.73-3.9514 \mathrm{X}_{1}-8.6925 \mathrm{X}_{2}-8.1393 \mathrm{X}_{1}^{2}-26.8461 \mathrm{X}_{2}^{2}+53.7525 \mathrm{X}_{1} \mathrm{X}_{2} & \mathrm{R}^{2}=0.91 \\
\text { Niacin }=22.80+42.3157 \mathrm{X}_{1}+19.3945 \mathrm{X}_{2}+27.2065 \mathrm{X}_{1}^{2}+8.7271 \mathrm{X}_{2}^{2}+10.6575 \mathrm{X}_{1} \mathrm{X}_{2} & \mathrm{R}^{2}=0.99 \\
\text { Pyridoxine }=101.141+10.6268 \mathrm{X}_{1}+0.3855 \mathrm{X}_{2}+33.7317 \mathrm{X}_{1}^{2}-6.3412 \mathrm{X}_{2}^{2}-22.53 \mathrm{X}_{1} \mathrm{X}_{2} & \mathrm{R}^{2}=0.76 \\
\text { Vitamin } \mathrm{C}=0.180+0.0609 \mathrm{X}_{1}+0.0133 \mathrm{X}_{2}-0.0331 \mathrm{X}_{1}^{2}-0.0480 \mathrm{X}_{2}^{2}+0.0025 \mathrm{X}_{1} \mathrm{X}_{2} & \mathrm{R}^{2}=0.93
\end{array}
$$

From the above equation, it can be concluded that thiamine had significant $(\mathrm{p}<0.0001)$ negative effect on linear model and $p<0.05$ on quadratic model. Yeast concentration and fermentation time had negative effect on thiamine and riboflavin at linear and quadratic level. Thiamine affected significantly $(p<0.0001)$ at linear level and was insignificant at quadratic level, while riboflavin was insignificant at linear level and fermentation time affected significantly $(p<0.01)$ at quadratic level. Niacin was highly significant $(p<0.0001)$ at linear level. Abbas $(2006)$ also reported that among the vitamins and other enzyme cofactors that are accumulated and/or synthesized by yeast are thiamine (vitamin $\mathrm{B}_{1}$ ), nicotinic acid, pyridoxine (vitamin $\mathrm{B}_{6}$ ) and pantothenic acid. Yeast concentration significantly $(\mathrm{p}<0.0001)$ affected niacin at quadratic level and fermentation time significantly affected at $\mathrm{p}<0.05$. Yeast concentration had a significant $(p<0.001)$ positive effect on vitamin $C$ at linear level, $p<0.01$ on $B_{6}$ at 
quadratic level while it was significant $(\mathrm{p}<0.01)$ negatively on vitamin $\mathrm{C}$ at quadratic level.

At interactive level, yeast and fermentation time affected the thiamine significantly at $p<0.0001$, riboflavin at $\mathrm{p}<0.001$, niacin at $\mathrm{p}<0.05$ while time had no significant effect on pyridoxine and Vitamin $\mathrm{C}$ retention. It is clear from figures $3 \mathrm{c}$ to $3 \mathrm{e}$, as there is increase in yeast concentration, there was increase in niacin, pyridoxine and vitamin $\mathrm{C}$ where thiamine and riboflavin were not influenced much. With increase in fermentation time there was decrease in B vitamins, thus the fermentation time has great influence on vitamin profile.

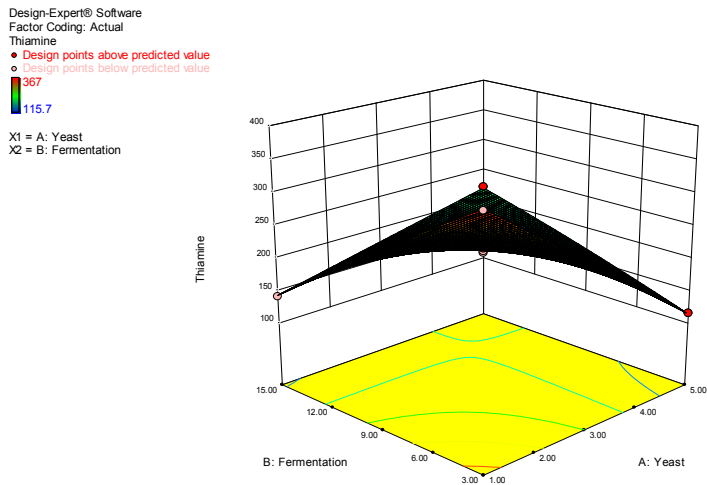

3a. Thiamine

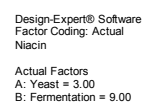

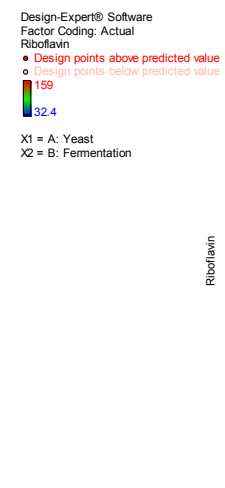

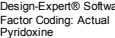
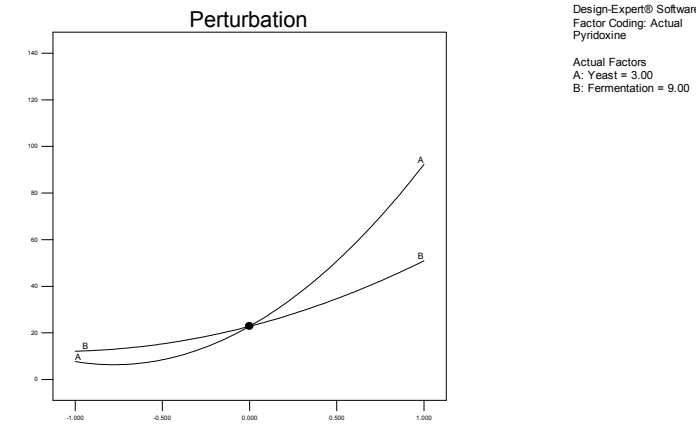

3c. Niacin

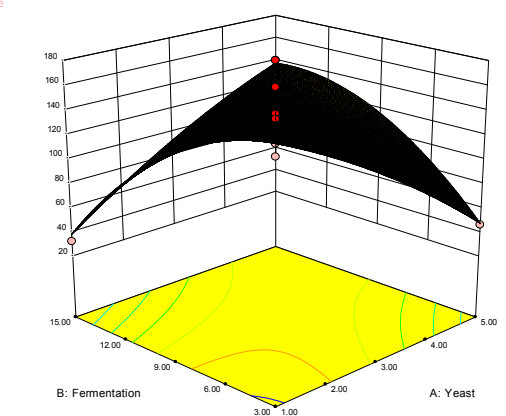

3b. Riboflavin

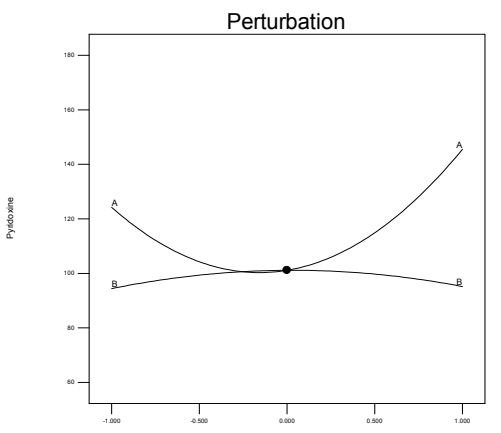

3d. Pyridoxine

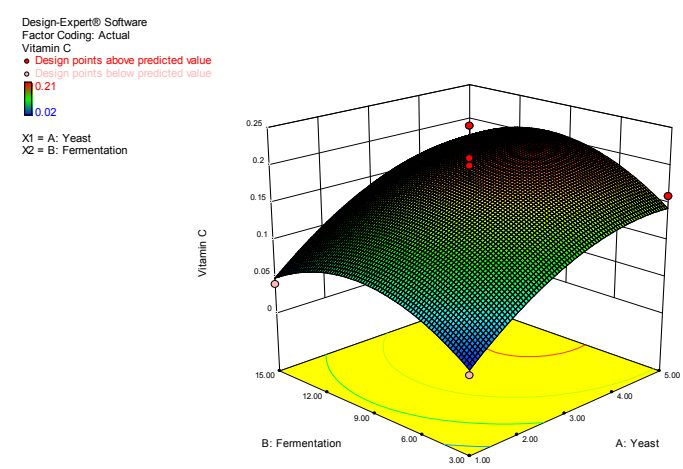

3e. Vitamin C

Figure 3. Perturbation graph and 3D plots depicting effect of independent variables on Nutritional Parameters of the fermented beverage 


\subsection{Optimization of Independent Variables}

Numerical optimization of independent variables, yeast and fermentation time were optimized using Design Expert Software. The criteria used along with the predicted and actual values of the response are given in Table 5 . The aim of the experiment was alcohol content was minimized and OAA was increased. The solution which was obtained was 3\% yeast and 3 days fermentation time with best fit desirability of 0.92 . The optimized results were total phenols $29.4 \mathrm{mg} \%$, antioxidants $13.34 \%$, acidity 0.22 , alcohol $4.7 \%$, total volatiles $0.0025 \%$, OAA 7.9 , vitamin $\mathrm{B}_{1} 255.7 \mu \mathrm{g} \%, \mathrm{~B}_{2} 119.6 \mu \mathrm{g} \%, \mathrm{~B}_{3} 51.1 \mu \mathrm{g} \%, \mathrm{~B}_{6} 149 \mu \mathrm{g} \%$ and vitamin-C $0.11 \mathrm{mg} \%$. The predicted response value as against actual value for responses as shown in Table 5 were in concurrence with each other, hence the similar fitted models are suitable for predicting the responses. Sensory score of optimized composition is given Table 4. The optimized fermented beverage had flavour 7.8, taste 7.8, consistency 8.0, colour 8.1 and overall acceptability score 7.8 .

Table 5. Predicted and actual response values

\begin{tabular}{lll}
\hline Responses & Predicted & Actual \\
\hline Total Phenols & 29.38 & 28.36 \\
Antioxidants & 13.34 & 12.6 \\
Acidity & 0.22 & 0.21 \\
Total Volatiles & 0.0025 & 0.0020 \\
Alcohol & 4.7 & 4.6 \\
OAA & 7.9 & 7.8 \\
Thiamine & 255.7 & 244.6 \\
Riboflavin & 119.6 & 78.6 \\
Niacin & 51.1 & 50.9 \\
Pyridoxine & 149 & 140 \\
Vitamin C & 0.11 & 0.17 \\
\hline
\end{tabular}

\section{Conclusion}

RSM showed that quadratic response surface models were fitted. F values were significant in all selected responses and a high $\mathrm{R}^{2}$ value of $>90 \%$ showed fitness of the polynomial regression models for describing the effect of variables. The results of the study indicated that the effect of yeast concentration and fermentation time were significant to all the selected responses and RSM could be useful in optimizing the yeast concentration and fermentation time with maximum retention of vitamins and minimum amount of alcohol formation. Using the optimized condition the prepared beverage from fermentation process contained more total phenolics, antioxidants, Vitamin $\mathrm{B}_{1}, \mathrm{~B}_{2}, \mathrm{~B}_{3}, \mathrm{~B}_{6}$ and Vitamin $\mathrm{C}$ when compared with fresh ashgourd juice. Since the alcohol content is within $5 \%$, it meets the PFA specifications under the food category. Overall the fermentation time and yeast concentration is optimized with maximum retention of vitamins, antioxidants and total phenols with $3 \%$ dry yeast concentration and 3 days fermentation time.

\section{Acknowledgement}

The authors sincerely thank the Director Dr. A S Bawa, DFRL, Mysore for his support and encouragement.

\section{References}

Abbas, C. A. (2006). Production of antioxidants, aromas, colours, flavours, and vitamins by yeasts. In Querol, A., \& Fleet, H. (Eds.), Yeasts in Food and Beverages, pp. 285-334. http://dx.doi.org/10.1007/978-3-540-28398-0_10

AOAC (1970). Official methods of analysis. Washington, DC: AOAC International.

Aslokar, L. V., Kakkar, K. K., \& Chakre, O. J. (1992). Glossary of Indian medicinal plants with active principles. ( $1^{\text {st }}$ ed.). New Delhi: CSIR Part I.

Campbell, P. G. (1994). Fermented foods - a world perspective. Food Research International, 27, 253-257. http://dx.doi.org/10.1016/0963-9969(94)90093-0 
Cruz, J. M., Domínguez, J. M., Domínguez, H., \& Parajo, J. C. (1999). Solvent extraction of hemicellulosic wood hydrolysates: a procedure useful for obtaining both detoxified fermentation media and polyphenols with antioxidant activity. Food Chemistry, 67, 147-153. http://dx.doi.org/10.1016/S0308-8146(99)00106-5

Arroyo Lopez F. N., Querol, A., Bautista-Gallego, J., \& Garrido-Fernandez A. (2008). Role of yeasts in table olive

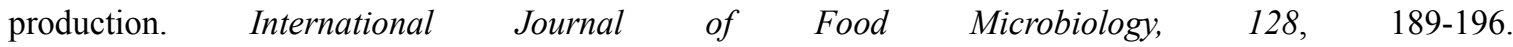
http://dx.doi.org/10.1016/j.ijfoodmicro.2008.08.018

Filomena, N., Florinda, F., Alfonso, S., \& Pierangelo. (2008). Synbiotic Potential of carrot juice supplemented with Lactobacillus spp and inulin or fructo oligosaccharides. Journal of the Science, 88, 2271

Ing $\mathrm{H}$ - Knauer, Rapid analysis of water-soluble vitamins using Smartline HPLC. [Online] Retrieved from: http://www.knauer.net/dwnld_fls/a_e_rapid_analysis_water_soluble_vitamins_hphp.pdf (April, 10)

Joshi, V. K., \& Devender, A. (2005). Panorama of research and development of wines in India. Journal of Scientific and Industrial Research, 64, 9-18.

Majumdar, T. K., Vasudish, C. R., Premavalli, K. S., \& Bawa, A. S. (2009). Preservation of functional vegetable juices: Ashgourd juice and Ashgourd-pudina blended juice. Beverage \& Food world, 48-50.

Majumdar, T. K., Vasudish, C. R., Premavalli, K. S., \& Bawa, A. S. (2010). Studies on processing and storage stability of ashgourd-mint leaves juice. Journal of Food Processing and Preservation, 34(2), 549-556.

Marica, R., Maja, V., Slavica, S. M., \& Milan, M. (2007). Contribution of lactic acid fermentation to improved nutritive quality vegetable juices enriched with brewer's yeast autolysate. Food Chemistry, 100, 599-602

Prachi Gupta., \& Premavalli, K. S. (2010). Effect of particle size reduction on physicochemical properties of ashgourd (Benincasa hispida) and radish (Raphanus sativus) fibres. International Journal of Food Sciences and Nutrition, 61(1), 18-28. http://dx.doi.org/10.3109/09637480903222186

Querol, A., \& Fleet, G. (2006). Yeasts in food and beverages. Springer-Verlag, Berlin. http://dx.doi.org/10.1007/978-3-540-28398-0

Ranganna, S. (1986). Handbook of Analysis and Quality Control for Fruits and Vegetable Products (2 ${ }^{\text {nd }}$ ed) New Delhi: Tata McGraw-Hill Publication.

Sandra, A. A., Jos, C. R. V., Iguatemy, L. B., Najeh, M. K., Ktia-Maria, S. C. L., Antonio-Baldo, G. M., \& Olga-Maria, M. F. O. (2009). Antioxidant activity, ascorbic acid and total phenol of exotic fruits occurring in Brazil. International Journal of Food Sciences and Nutrition, 60, 439-448. http://dx.doi.org/10.1080/09637480701780641

Sivarajan, V. V., \& Balachandran, I. (1994). Ayurvedic drugs and their plant sources (1 $1^{\text {st }}$ ed.). New Delhi: Oxford and IBH Publishing.

Viljoen, B. C. (2006). Yeast ecological interactions. Yeast-yeast, yeast bacteria, yeast-fungi interactions and yeasts as biocontrol agents. In Querol, A., \& Fleet, H. (Eds.), Yeasts in Food and Beverages, pp. 83-110. Springer-Verlag, Berlin. http://dx.doi.org/10.1007/978-3-540-28398-0_4

Wadikar, D. D., Nanjappa, C., Premavalli, K. S., \& Bawa, A. S. (2010). Development of ginger based ready-to-eat appetizers by Response surface methodology. Appetite, 55, 76-83. http://dx.doi.org/10.1016/j.appet.2010.04.004

Yoon, K. Y., Woodams, E. E., \& Hang, Y. D. (2006). Production of probiotic cabbage juice by lactic acid bacteria. Bioresource Technology, 97, 1427-1430. http://dx.doi.org/10.1016/j.biortech.2005.06.018 